\title{
Effect of Postweld Heat Treatments on Type IV Creep Failure in the Intercritical Heat-Affected Zone of $10 \%$ Cr Martensitic Steel Welded with Haynes 282 Filler
}

\author{
Namkyu Kim ${ }^{1,2}$, Yongjoon Kang ${ }^{3}$, Jinhyeok Bang ${ }^{3}$, Sangwoo Song ${ }^{3}{ }^{(D)}$, Seong-Moon Seo ${ }^{4}$, Chung-Yun Kang ${ }^{5, *}$ \\ and Namhyun Kang $2, *$ (D) \\ 1 Department of Authorized Nuclear Inspection, Korea Institute of Materials Science (KIMS), Changwon 51508, \\ Korea; nkkim@kims.re.kr \\ 2 Division of Materials Science and Engineering, Pusan National University, Busan 46241, Korea \\ 3 Department of Joining Technology, Korea Institute of Materials Science (KIMS), Changwon 51508, Korea; \\ yjkang@kims.re.kr (Y.K.); bjhyug@kims.re.kr (J.B.); swsong@kims.re.kr (S.S.) \\ 4 Department of High Temperature Materials, Korea Institute of Materials Science (KIMS), Changwon 51508, \\ Korea; castme@kims.re.kr \\ 5 Industrial Liaison Innovation Center, Pusan National University, Busan 46241, Korea \\ * Correspondence: kangcy@pusan.ac.kr (C.-Y.K.); nhkang@pusan.ac.kr (N.K.)
}

check for

updates

Citation: Kim, N.; Kang, Y.; Bang, J.; Song, S.; Seo, S.-M.; Kang, C.-Y.; Kang, N. Effect of Postweld Heat Treatments on Type IV Creep Failure in the Intercritical Heat-Affected Zone of $10 \%$ Cr Martensitic Steel Welded with Haynes 282 Filler. Metals 2021, 11, 726. https://doi.org/ $10.3390 / \operatorname{met} 11050726$

Academic Editor: Stefano Spigarelli

Received: 11 March 2021

Accepted: 21 April 2021

Published: 28 April 2021

Publisher's Note: MDPI stays neutral with regard to jurisdictional claims in published maps and institutional affiliations.

Copyright: (c) 2021 by the authors. Licensee MDPI, Basel, Switzerland. This article is an open access article distributed under the terms and conditions of the Creative Commons Attribution (CC BY) license (https:/ / creativecommons.org/licenses/by/ $4.0 /)$.
Abstract: This study investigated the effect of postweld heat treatment (PWHT) conditions on Type IV failure behavior of $10 \% \mathrm{Cr}$ martensitic steel welds using Haynes 282 filler. The welded joints were subjected to PWHT at temperatures of 688,738 , and $788^{\circ} \mathrm{C}$ for 4 and $8 \mathrm{~h}$. Creep tests were carried out at $600{ }^{\circ} \mathrm{C}$ under a stress of $200 \mathrm{MPa}$. The as-welded joint without PWHT showed Type IV cracking due to growth of voids around Laves phase by localized creep deformation in the intercritical heataffected zone (ICHAZ). The creep properties of the PWHTed joints at $688^{\circ} \mathrm{C}$ were similar to those of the as-welded joints without PWHT. On the other hand, the PWHTed joints at $738^{\circ} \mathrm{C}$ exhibited a significantly longer creep life by a lower amount of Laves phase in the ICHAZ than those at $688^{\circ} \mathrm{C}$; this could be a result of the homogenization of ICHAZ microstructure during PWHT at $738^{\circ} \mathrm{C}$. However, the PWHT at 688 and $738^{\circ} \mathrm{C}$ showed the same Type IV creep failure mode. Meanwhile, the PWHTed joints at $788{ }^{\circ} \mathrm{C}$ exhibited the shortest creep life in this study. The failure location was shifted to the base metal away from the HAZ, and severe plastic deformation occurred due to the softened matrix by excessive tempering.

Keywords: postweld heat treatment; heat-affected zone; creep test; Type IV cracking; $10 \%$ Cr martensitic steel

\section{Introduction}

Increasing the operating efficiency of fossil fuel power plants by raising the service temperature and pressure is necessary because of environmental considerations. Power plants operating under ultra-super-critical (USC) or advanced USC (A-USC) conditions require heat-resistant materials with enhanced creep resistance [1-6]. Normally, Ni-based superalloys are employed for high-temperature applications above $670{ }^{\circ} \mathrm{C}$, and advanced high-chromium $(9-12 \% \mathrm{Cr})$ martensitic steels are used at the temperature lower than $670{ }^{\circ} \mathrm{C}$ [6-12]. Consequently, dissimilar metal welds (DMWs) between Ni-based superalloys and $9-12 \%$ Cr martensitic steels are inevitable in USC and A-USC power plants. Thus, for successful long-term operation under a high temperature and pressure environment, it is necessary to investigate the creep behavior of the DMWs.

The creep rupture of DMWs between Ni-based superalloys and ferritic/martensitic steels occurred in the steel side (i.e., base metal (BM), heat-affected zone (HAZ), and fusion line) because of its relatively lower creep strength [13-15]. For 9-12\% Cr martensitic steel welded joints, it is reported that creep rupture normally occurs in the fine-grained HAZ 
(FGHAZ) or intercritical HAZ (ICHAZ) with relatively little total crossweld strain under long-term creep conditions, commonly known as Type IV failure. Thus, Type IV failure in the HAZ of $9-12 \%$ Cr martensitic steels should be clarified and remedied to ensure high safety and reliability of the component composed of the DMWs for use under USC or A-USC conditions. However, Type IV cracking in the DMWs is still not clearly understood, although it is reported to be associated with softening of the matrix, formation of Laves phase, coarsening of precipitates, and lack of sufficient precipitates pinning the grain boundaries [16-20].

Several studies have reported that PWHT is effective in retarding Type IV cracking and increasing creep life of the HAZ of 9-12\% Cr martensitic steels [20-23]. On the other hand, some researchers reported that the creep rupture strength after PWHT is lower than that in the as-welded condition [24-26]. The mechanism of retarding Type IV failure by PWHT has not been elucidated, and optimal PWHT conditions for the creep properties have not been determined.

In this study, the effect of various PWHT conditions on Type IV failure behavior and microstructure evolution of $10 \% \mathrm{Cr}$ martensitic steel welded joint was investigated. The mechanism to increase the creep properties is discussed based on the microstructural observation occurring in the ICHAZ during the creep testing.

\section{Experimental Procedures}

\subsection{Materials, Welding Procedure, and PWHT Conditions}

For preparation of the welded joints, $10 \% \mathrm{Cr}$ martensitic steel plates of $10 \mathrm{~mm}$ thickness were used. They were normalized at $1100{ }^{\circ} \mathrm{C}$ for $1 \mathrm{~h}$ and tempered at $700{ }^{\circ} \mathrm{C}$ for $30 \mathrm{~h}$. The authors' previous study reported that the $10 \% \mathrm{Cr}$ steel BM consists of a typical tempered martensite structure with coarse $\mathrm{Cr}$-rich $\mathrm{M}_{23} \mathrm{C}_{6}$ and fine V-rich MC precipitates [27]. The $\mathrm{A}_{\mathrm{C} 1}$ and $\mathrm{A}_{\mathrm{C} 3}$ transformation temperatures measured by a differential scanning calorimeter (DSC, NETZSCH 404C) were 852 and $895^{\circ} \mathrm{C}$, respectively. Chemical compositions of the $10 \% \mathrm{Cr}$ steel and Haynes 282 filler are listed in Table 1.

Table 1. Chemical composition of the $10 \% \mathrm{Cr}$ steel BM and Haynes 282 filler metal.

\begin{tabular}{cccccccccccc}
\hline & \multicolumn{10}{c}{ Chemical Compositions (wt.\%) } \\
\cline { 2 - 12 } & $\mathbf{C}$ & $\mathbf{C r}$ & $\mathbf{C o}$ & $\mathbf{M o}$ & $\mathbf{W}$ & $\mathbf{V}$ & $\mathbf{N b}$ & $\mathbf{T i}$ & $\mathbf{A l}$ & $\mathbf{F e}$ & $\mathbf{N i}$ \\
\hline $10 \%$ Cr steel & 0.08 & 9.8 & 2.7 & 0.7 & 1.6 & 0.2 & 0.06 & - & - & Bal. & - \\
\hline Haynes 282 & 0.06 & 19.44 & 10.28 & 8.5 & - & - & - & 2.22 & 1.47 & 0.32 & Bal. \\
\hline
\end{tabular}

Welding was performed using automatic gas tungsten arc welding (GTAW) process with Haynes 282 filler wire. A single V-groove of $60^{\circ}(7 \mathrm{~mm}$ in depth) was prepared for weld deposition. Two-layer welding with two passes was carried out, and the interpass temperature was $48^{\circ} \mathrm{C}$. The voltage and current used in the welding process were $10-14 \mathrm{~V}$ and 236-240 A, respectively. The details of welding process are shown in Figure 1a. The creep specimen was collected from the red-dotted box in Figure 1a, and the detailed dimensions of the creep specimen are shown in Figure 1b. Cylindrical specimens with a gauge diameter of $4 \mathrm{~mm}$ and gauge length of $25 \mathrm{~mm}$ were employed for creep tests. 
(a)

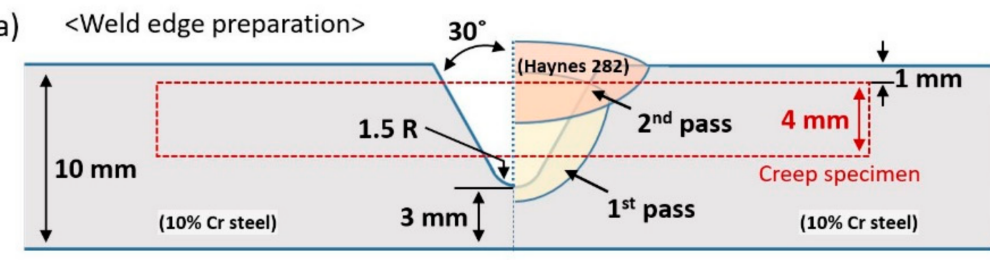

$<$ Welding process details>

\begin{tabular}{|ll|} 
Welding current (A) & $236-240$ \\
Voltage $(\mathrm{V})$ & $10-12\left(1^{\text {st }}\right.$ pass $)$ \\
Welding speed (mm/s) & $11-14\left(2^{\text {nd }}\right.$ pass $)$ \\
Shielding gas & Pure Ar \\
Preheat temp. & N/A \\
Interpass temp. $\left({ }^{\circ} \mathrm{C}\right)$ & 48 \\
Filler metal dia. $(\mathrm{mm})$ & 2.4 \\
\hline
\end{tabular}

(b)
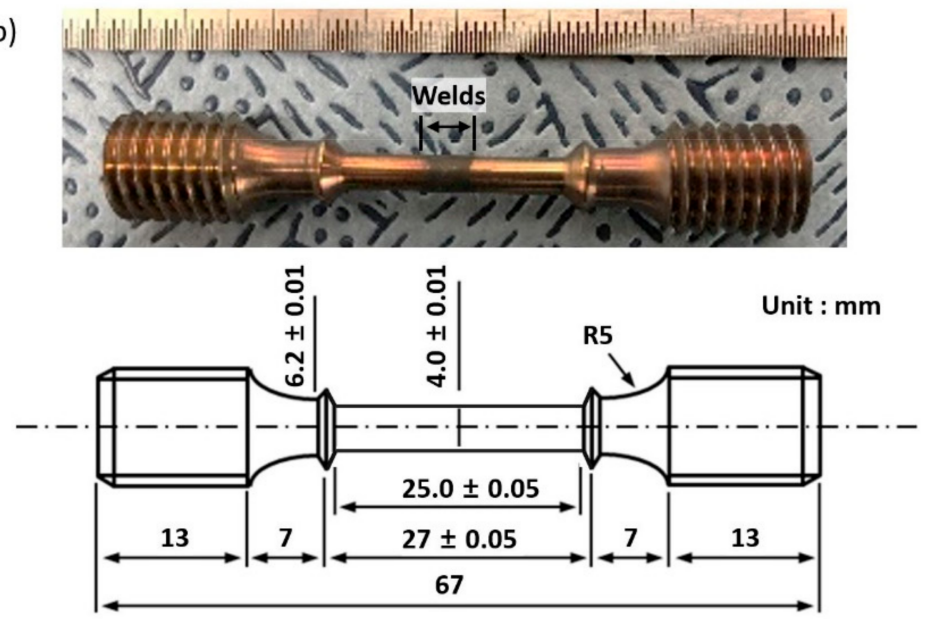

Figure 1. (a) Schematic diagram of weld-edge preparation and welding conditions; (b) shape and dimensions of creep test specimen.

ASME Boiler and pressure vessel code Section I requires that PWHT of 9-12\% Cr martensitic steels is carried out in a temperature range of $675-785^{\circ} \mathrm{C}$. After welding, the welded joints were subjected to PWHT at various temperatures $\left(688,738\right.$, and $\left.788^{\circ} \mathrm{C}\right)$ for 4 and $8 \mathrm{~h}$. The PWHT temperature of $688^{\circ} \mathrm{C}$ is lower than the tempering temperature of $700{ }^{\circ} \mathrm{C}$ on the $\mathrm{BM}$ and above the lower limit of the required PWHT temperature range of $9-12 \%$ Cr steels. The temperature of $738^{\circ} \mathrm{C}$ is the normally recommended PWHT temperature of $9-12 \% \mathrm{Cr}$ steels and higher than the tempering temperature of the $\mathrm{BM}$. The PWHT temperature of $788^{\circ} \mathrm{C}$ is one of the suggested single-step aging temperature of Haynes 282 [28] and similar to the upper limit of the required PWHT temperature range of $9-12 \%$ Cr steels. All of the PWHT temperatures are lower than the $\mathrm{A}_{\mathrm{C} 1}$ temperature of the BM.

\subsection{Creep and Mechanical Testing}

Creep tests were carried out at $600{ }^{\circ} \mathrm{C}$ under constant load corresponding to a stress of $200 \mathrm{MPa}$ using an ATS (series 2300) machine. The welded joint was in the center of the specimen and within the gauge length (Figure 1b). Creep tests were also conducted on the BM for comparison. To investigate the Type IV cracking mechanism, creep interruption testing was additionally conducted at $630^{\circ} \mathrm{C}$ under the stress of $150 \mathrm{MPa}$ for the as-welded specimen.

Hardness profiles across the welded joint were measured at room temperature using a micro-Vickers hardness tester (LECO, LM248AT, MI, USA) with a loading force of $0.2 \mathrm{kgf}$ and a dwell time of $13 \mathrm{~s}$. The interval between two hardness measurement points was fixed at $200 \mu \mathrm{m}$.

Nano-indentation test was performed using a Nano Indenter XP (MTS, MN, USA) to measure the microhardness of each subzone. The nano-indentation test was performed in a displacement control mode in which the indenter moves into the sample up to a pre-set maximum indentation depth. The maximum indentation depth was set to $200 \mathrm{~nm}$. At the maximum indentation depth, the indenter was kept for $10 \mathrm{~s}$, and then the indenter is pulled out. 


\subsection{Microstructural Characterization}

The samples were grounded using from 400 to 1200 grit sand-paper and smoothed by $1 \mu \mathrm{m}$ diamond paste. The microstructures of the welded joints were observed by optical microscopy (OM, Olympus_BX53M, Tokyo, Japan), field emission scanning electron microscopy (FE-SEM, JSM_7001F, Akishima, Japan), and transmission electron microscopy (TEM, JEM_2100F, Akishima, Japan). Villela's reagent (1 g picric acid + $5 \mathrm{~mL} \mathrm{HCl}+100 \mathrm{~mL}$ ethanol) was used to etch the $10 \% \mathrm{Cr}$ steel side for observation in OM and SEM. SEM backscattered electron (BSE) images were used to distinguish the $\mathrm{W}$ and Mo-rich Laves phase (bright contrast) from $\mathrm{M}_{23} \mathrm{C}_{6}$ particles (dark contrast) $[29,30]$. The area fraction and average size of the precipitates were measured from the SEM/BSE images using Image-Pro analysis software (Media Cybernetics, Inc., Rockville, MD, USA; Version 4.5). The chemical compositions and elemental distribution were analyzed by energy dispersive spectroscopy (EDS, JSM_7001F) and electron probe microanalyzer (EPMA, JXA_8530F, Akishima, Japan), respectively. Electron backscatter diffraction (EBSD, JSM_7001F) with inverse pole figure (IPF) and kernel average misorientation (KAM) analysis was used to evaluate the strain distribution on the HAZ.

\section{Results and Discussion}

\subsection{Creep and Rupture Behavior for Various PWHT Conditions}

Creep curves obtained at $600{ }^{\circ} \mathrm{C} / 200 \mathrm{MPa}$ are shown in Figure 2. The as-welded specimen ruptured at $2763 \mathrm{~h}(\sim 40 \%$ below base metal). The creep properties of the PWHTed joints at $688{ }^{\circ} \mathrm{C}$ were similar to those of the as-welded joints without PWHT. On the other hand, the specimens with PWHT temperature of $738^{\circ} \mathrm{C}$ exhibited better creep properties, such as rupture life and total strain, than those of the $688^{\circ} \mathrm{C}$ PWHTed specimens. Specifically, the maximum creep rupture life of $5043 \mathrm{~h}$ was measured for the $738^{\circ} \mathrm{C}-8 \mathrm{~h}$ PWHT condition, and it was $160 \%$ higher than that of the $688^{\circ} \mathrm{C}$ PWHT conditions.

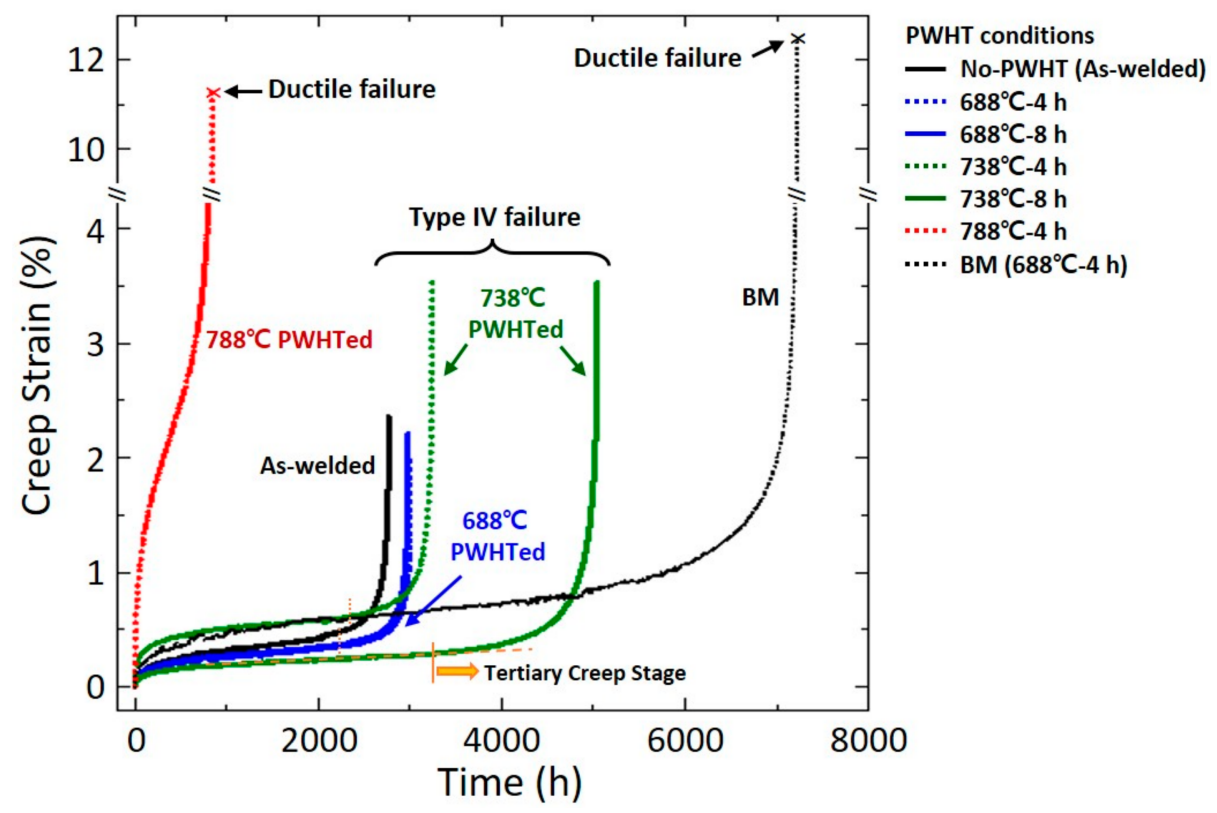

Figure 2. Comparison of the creep curves at $600{ }^{\circ} \mathrm{C} / 200 \mathrm{MPa}$ under various PWHT conditions.

The results obtained for the creep tests are summarized in Table 2. All the creep fractures occurred in the $10 \% \mathrm{Cr}$ steel side such as HAZ and unaffected BM. The creep test results of the base metal with PWHT at 688 and $788^{\circ} \mathrm{C}$ are also shown in Table 2 for comparison. Cross-sectional images of the creep-ruptured specimens are shown in Figure 3. The blue and white dotted lines in Figure 3 represent the locations of the BM/HAZ boundary and Type IV failure, respectively. The as-welded specimen indicated the Type IV cracking failure occurred in the ICHAZ (close to FGHAZ). The application of PWHT at 688 
and $738{ }^{\circ} \mathrm{C}$ did not change the Type IV creep failure mode. However, the PWHT at $788^{\circ} \mathrm{C}$ shifted the failure location to the BM.

Table 2. Summary of creep test results. All tests were performed at $600{ }^{\circ} \mathrm{C} / 200 \mathrm{MPa}$.

\begin{tabular}{|c|c|c|c|c|c|c|}
\hline & \multicolumn{2}{|c|}{ Heat Treatment Condition } & \multirow{2}{*}{ Time to Rupture $\left(t_{r}\right)$} & \multirow{2}{*}{ Fracture Strain $\left(\varepsilon_{r}\right)$} & \multirow{2}{*}{$\begin{array}{l}\text { Min. Creep Rate } \\
(\% / \mathrm{h})\end{array}$} & \multirow{2}{*}{$\begin{array}{c}\text { Fracture } \\
\text { Type/Location }\end{array}$} \\
\hline & Temp. & Time & & & & \\
\hline \multirow{4}{*}{ Welds } & \multicolumn{2}{|c|}{ As-welded (no PWHT) } & 2763.72 & 2.37 & $1.0518 \times 10^{-4}$ & Type IV/HAZ \\
\hline & $688^{\circ} \mathrm{C}$ & $\begin{array}{l}4 \mathrm{~h} \\
8 \mathrm{~h}\end{array}$ & $\begin{array}{l}3002.35 \\
2973.41\end{array}$ & $\begin{array}{l}2.04 \\
2.21\end{array}$ & $\begin{array}{l}7.5148 \times 10^{-5} \\
7.8253 \times 10^{-5}\end{array}$ & $\begin{array}{l}\text { Type IV / HAZ } \\
\text { Type IV / HAZ }\end{array}$ \\
\hline & $738^{\circ} \mathrm{C}$ & $\begin{array}{l}4 \mathrm{~h} \\
8 \mathrm{~h}\end{array}$ & $\begin{array}{l}3242.06 \\
5043.45\end{array}$ & $\begin{array}{l}3.57 \\
3.52\end{array}$ & $\begin{array}{l}7.7919 \times 10^{-5} \\
4.1833 \times 10^{-5}\end{array}$ & $\begin{array}{l}\text { Type IV /HAZ } \\
\text { Type IV/HAZ }\end{array}$ \\
\hline & $788^{\circ} \mathrm{C}$ & $4 \mathrm{~h}$ & 845.05 & 11.33 & $2.6859 \times 10^{-3}$ & Ductile/BM \\
\hline \multirow{2}{*}{$\mathrm{BM}$} & $688^{\circ} \mathrm{C}$ & $4 \mathrm{~h}$ & 7219.99 & 12.43 & $1.0928 \times 10^{-4}$ & Ductile \\
\hline & $788^{\circ} \mathrm{C}$ & $4 \mathrm{~h}$ & 623.08 & 18.97 & $8.6771 \times 10^{-3}$ & Ductile \\
\hline
\end{tabular}

(a) $688^{\circ} \mathrm{C}-8 \mathrm{~h}$ PWHTed $\left(t_{r}: 2973 \mathrm{~h}\right)$

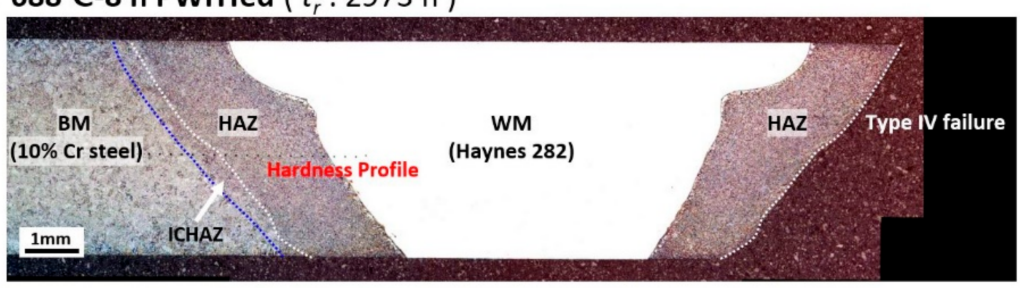

(b) $738^{\circ} \mathrm{C}-8 \mathrm{~h}$ PWHTed $\left(t_{r}: 5043 \mathrm{~h}\right)$

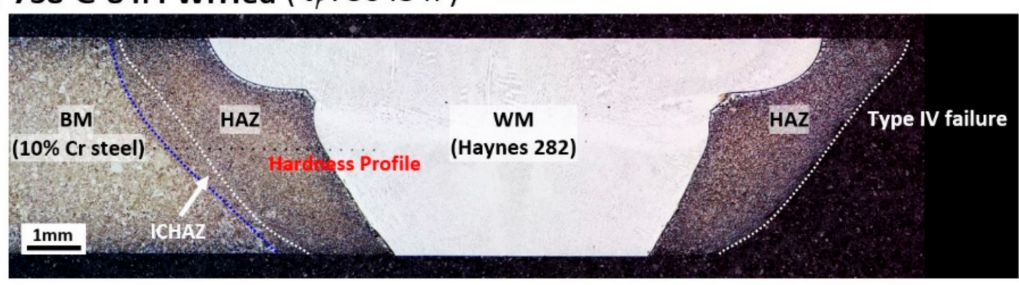

(c) $788^{\circ} \mathrm{C}-4 \mathrm{~h}$ PWHTed $\left(t_{r}: 845 \mathrm{~h}\right)$

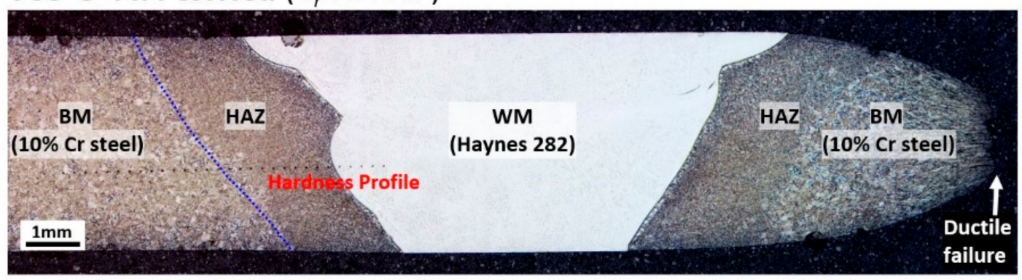

Figure 3. Cross-sectional images of creep specimens with different PWHT conditions: (a) $688^{\circ} \mathrm{C}-8 \mathrm{~h}$; (b) $738{ }^{\circ} \mathrm{C}-8 \mathrm{~h}$; and (c) $788^{\circ} \mathrm{C}-4 \mathrm{~h}$ PWHTed specimens.

Hardness profiles across the weldments in as-welded $688^{\circ} \mathrm{C}-8 \mathrm{~h}, 738^{\circ} \mathrm{C}-8 \mathrm{~h}$, and $788^{\circ} \mathrm{C}-4 \mathrm{~h}$ PWHT conditions before and after the creep test at $600{ }^{\circ} \mathrm{C} / 200 \mathrm{MPa}$ are shown in Figure 4 . Hardness after the creep test was measured on a cross-section of the nonfractured side of the specimens (Figure 3). Based on the results of the hardness measurements and microstructural observation, fusion line, coarse-grained HAZ (CGHAZ), FGHAZ, ICHAZ, over-tempered zone (OTZ), and BM were identified. 

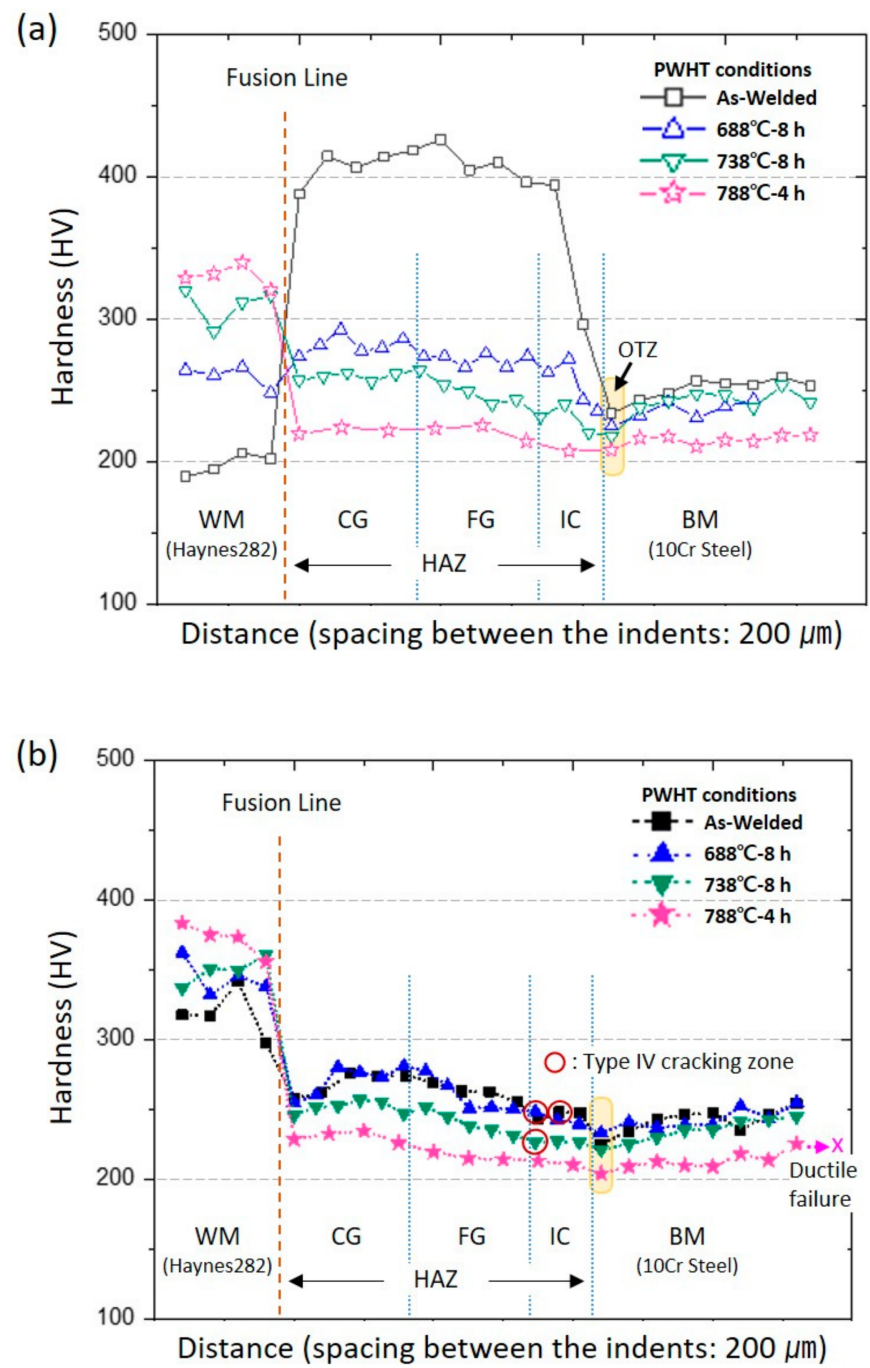

Figure 4. Hardness profile near the weld interface before and after creep test at $600{ }^{\circ} \mathrm{C} / 200 \mathrm{MPa}$ : (a) before creep test and (b) after creep test.

Figure 4a shows the hardness distribution under various PWHT conditions before the creep test. The high hardness (above $400 \mathrm{HV}$ ) in the as-welded HAZ is attributed to formation of martensite because of high peak temperature during welding. PWHT reduced the hardness of the HAZ considerably due to the evolution of precipitates as a result of a tempering reaction and the formation of tempered martensite. Hardness of the HAZ decreased with an increasing the PWHT temperature. The hardness difference between the $\mathrm{HAZ}$ and the $\mathrm{BM}$ was reduced significantly after PWHT above $738^{\circ} \mathrm{C}$, and relatively uniform hardness distribution was observed.

Figure $4 \mathrm{~b}$ shows the hardness distribution on the nonfractured side of the specimens after the creep test. For a PWHT temperature of $688^{\circ} \mathrm{C}$, the FGHAZ and ICHAZ suffered a slightly greater loss in hardness than the other regions during creep exposure. On the other hand, in the $738{ }^{\circ} \mathrm{C}$ PWHTed specimens, no significant differences in the hardness profiles were found after the creep tests in spite of the longer creep rupture life. For all the creep specimens with Type IV cracking, it should be noted that the creep failure occurred in the ICHAZ even though its hardness was higher than that of the OTZ adjacent to the outer edge of the HAZ. The region with the lowest hardness is normally considered to be the cracking susceptible region. In this study, however, hardness minima across the welds did not represent the Type IV cracking region.

The creep rupture life for the specimens with PWHT at $788^{\circ} \mathrm{C}-4 \mathrm{~h}$ was $845 \mathrm{~h}$, which was much lower than that in the as-welded and other PWHT conditions (Figure 2). How- 
ever, the fracture strain values of these specimens were considerably larger $(\sim 12 \%)$ because ductile failure with extensive necking occurred in the BM (Figure 3c). Numerous studies have been reported that the creep failure location shifts from the ICHAZ (Type IV cracking) to the BM (ductile failure) with increase in applied stress [14,19,30-33]. In the present study, increasing the PWHT temperature from 738 to $788^{\circ} \mathrm{C}$ caused a transition of the creep rupture mode from Type IV failure to ductile failure even though creep tests were carried out under the same condition. As shown in Figure 4, the HAZ and BM hardness decreased considerably after PWHT at $788^{\circ} \mathrm{C}$ as a result of sufficient tempering at high temperature (much higher than tempering temperature of the BM). Therefore, PWHT at $788^{\circ} \mathrm{C}$ decreases the creep strength of $10 \% \mathrm{Cr}$ steel, and the fracture mechanism of the ductile failure controlled by plastic deformation is expected to be applied as same as that creep failure under higher applied stress [15,34-36].

\subsection{Type IV Failure Mechanism in the ICHAZ}

In order to clarify the reason why the Type IV failure is promoted in the ICHAZ even though the lowest hardness region was observed in the OTZ (Figure 4b), a creep interruption test was conducted at $630^{\circ} \mathrm{C}$ under the stress of $150 \mathrm{MPa}$. The macrostructure of the as-welded (non-PWHTed) specimen after the creep interruption test for $1446 \mathrm{~h}$ (time to minimum creep rate, $t_{m}+346 \mathrm{~h}$ ) is shown in Figure $5 \mathrm{a}$, and a little deformation was observed only at the outer edge $(\sim 100 \mu \mathrm{m})$ of the right-hand side ICHAZ. Large numbers of small creep voids were observed in the deformed ICHAZ after the creep interruption test. It should be noted that no creep voids were observed in the ICHAZ of the un-deformed side (left-hand side of specimen in Figure 5a) after the creep test, which suggests that the un-deformed part of the specimen was still in the secondary (steady state) or early tertiary creep stage. In other words, only the ICHAZ of the creep deformed side experienced the tertiary creep stage.

(a)
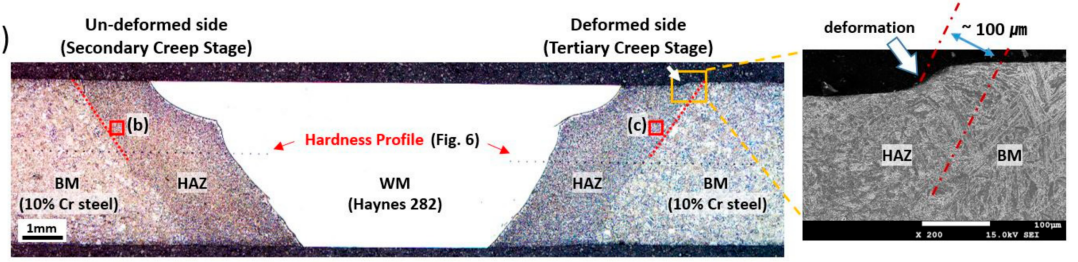

(b)

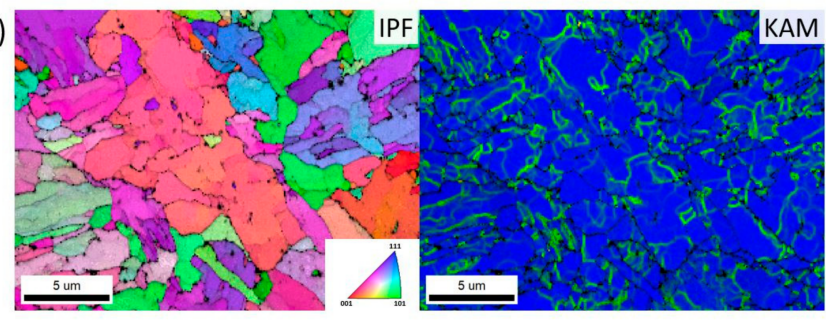

(c)

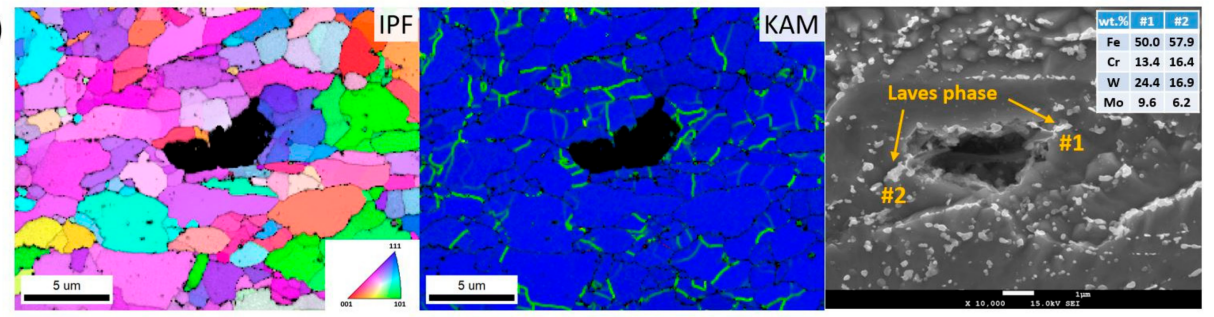

Figure 5. Creep interruption results conducted at $630^{\circ} \mathrm{C} / 150 \mathrm{MPa}$ : (a) macro image following creep interruption test; and EBSD (IPF and KAM) analysis for (b) un-deformed ICHAZ and (c) deformed ICHAZ (including EDS analysis of the precipitates marked with arrows). 
Figure $5 b, c$ show EBSD analysis (IPF and KAM) of the un-deformed and deformed ICHAZ, respectively, after the creep interruption test. In the ICHAZ of the un-deformed region (regarded as the secondary creep stage), the strain concentration was mainly distributed at the vicinity of the gain boundaries, and the overall strain distribution is relatively homogeneous (Figure 5b). During the tertiary creep stage (deformed region, right-hand side of specimen in Figure 5a), a remarkable decrease of strain concentration and an increase of new subgrains was observed, indicating accelerated recovery processes (Figure 5c). In addition, the creep voids were formed at the fine PAGBs, and many coarse $\mathrm{W}$ and Mo-rich Laves phase $\left((\mathrm{Fe}, \mathrm{Cr})_{2}(\mathrm{~W}, \mathrm{Mo})\right)$ particles were observed around the voids. The precipitation of the Laves phase is considered to be the main cause of Type IV cracking in 9-12\% Cr steel because the nucleation and growth of the Laves phase promote diffusion of $\mathrm{W}$ or Mo from the matrix to the Laves phase, which results in the loss of solid solution strengthening and deteriorates the creep properties. When the Laves phase precipitates on the grain boundaries, the sliding of grain boundary during creep could lead to stress-strain concentration at the Laves phase/matrix interface, which results in the nucleation and growth of the creep void [10-12,19,32,37].

The Vickers hardness profiles on the creep interrupted specimens (Figure 5a) are plotted in Figure 6. The hardness curve of the nonfractured part of the as-welded specimen $\left(t_{r}: 2763 \mathrm{~h}\right.$ ) after the creep test at $600{ }^{\circ} \mathrm{C} / 200 \mathrm{MPa}$ is also shown (as dotted lines with closed rectangular symbol) in the same figure for comparison. Hardness distributions of the undeformed region at the $630^{\circ} \mathrm{C} / 150 \mathrm{MPa}$ showed a similar trend to those of the specimen crept at the $600{ }^{\circ} \mathrm{C} / 200 \mathrm{MPa}$ condition. However, the ICHAZ of the deformed region showed considerably lower hardness than that of the un-deformed region, and the lowest hardness $(\sim 200 \mathrm{HV})$ appeared in the ICHAZ during the tertiary creep stage corresponding to the Type IV failure location. The largest decrease in hardness indicates the large local recovery at the location (Figure $5 \mathrm{c}$ ). The localized deformation in the outer edge of the HAZ shown in Figure 5a is correlated with this softened zone, and a critical amount of strain was concentrated for creep voids to occur.

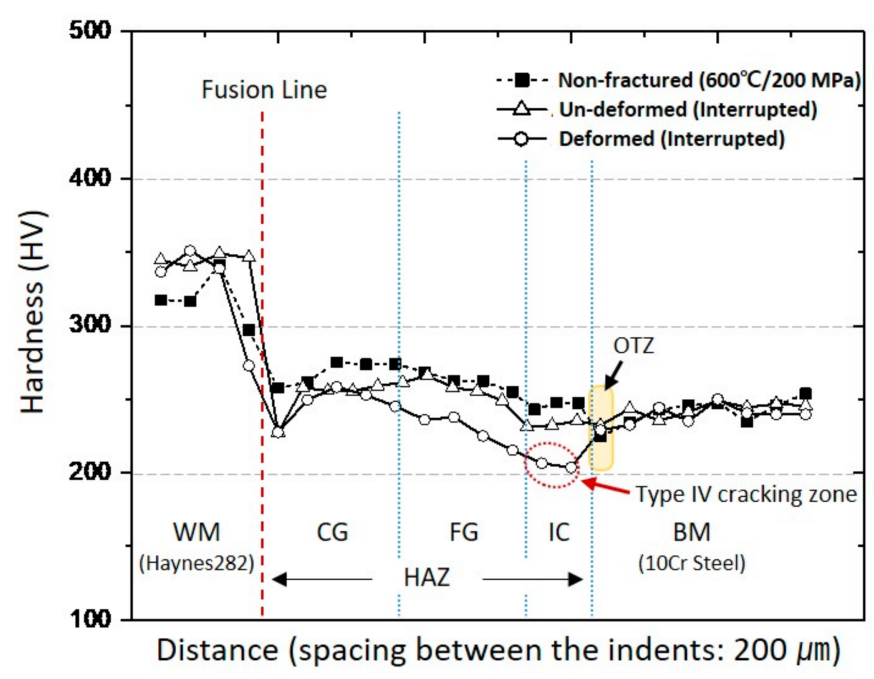

Figure 6. Hardness profile across the weldments in as-welded condition after creep interruption test at $630^{\circ} \mathrm{C} / 150 \mathrm{MPa}$ (including the hardness profile observed for the specimen crept at $600^{\circ} \mathrm{C} / 200 \mathrm{MPa}$ ).

After the creep test at $600{ }^{\circ} \mathrm{C} / 200 \mathrm{MPa}$, the detailed microstructural analysis of the ICHAZ (nonfractured side) in the as-welded specimen are shown in Figure 7. During welding, the ICHAZ region heated to a maximum temperature between $A_{C 1}$ and $A_{C 3}$, and the original tempered martensite partially transformed to austenite upon heating which then transformed to fresh untempered martensite upon cooling $[14,23,26,38]$. Both newly transformed fine prior austenite grain boundaries (PAGBs) and former PAGBs decorated by a large number of precipitates were observed in the ICHAZ (Figure 7a). 
Two types of precipitates were identified by TEM/EDS analysis (Figure $7 \mathrm{~b}, \mathrm{c}$ ). Cr-rich $\mathrm{M}_{23} \mathrm{C}_{6}$ carbides indicated by the red arrows were distributed along the former PAGBs and packet/block boundaries. Meanwhile, W and Mo-rich Laves phase indicated by the yellow arrows were precipitated along the newly formed fine PAGBs as well as the former PAGBs.

(a)

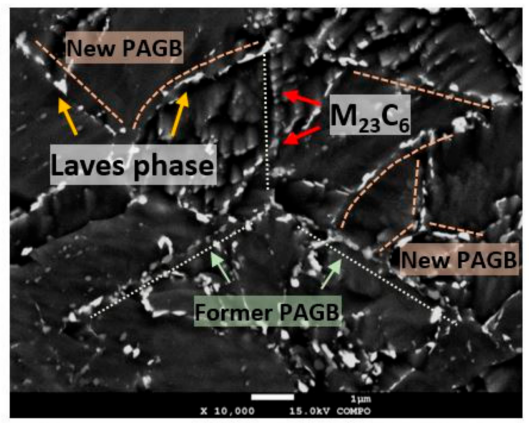

(b) BF

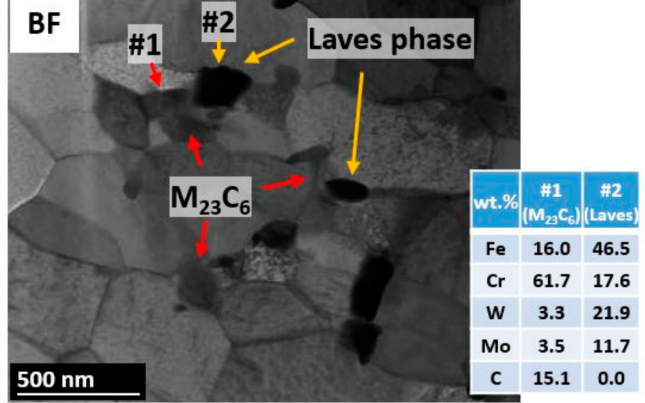

(c)

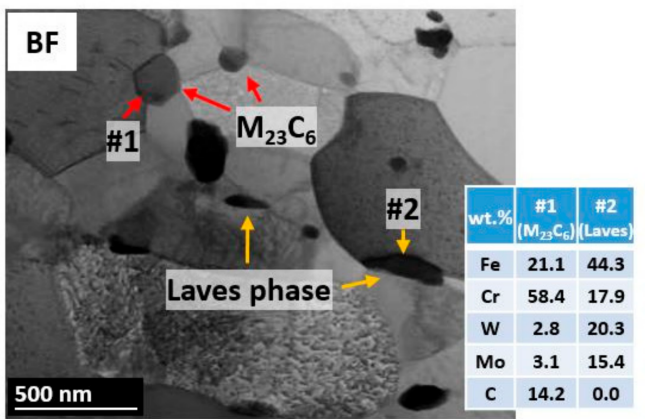

(d)

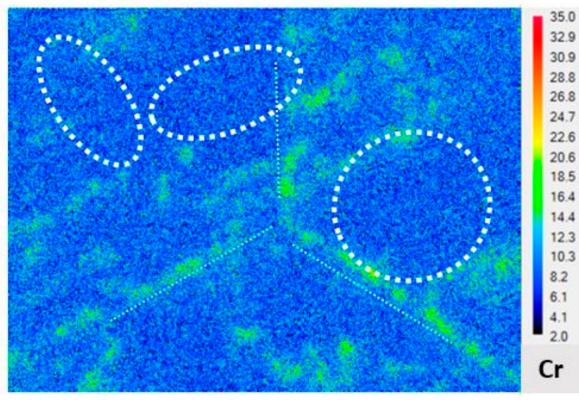

(e)

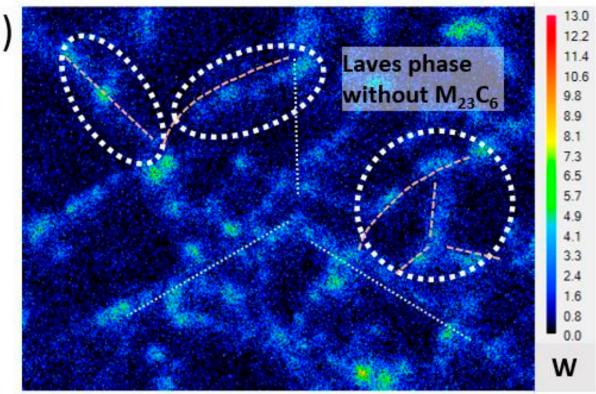

(f)

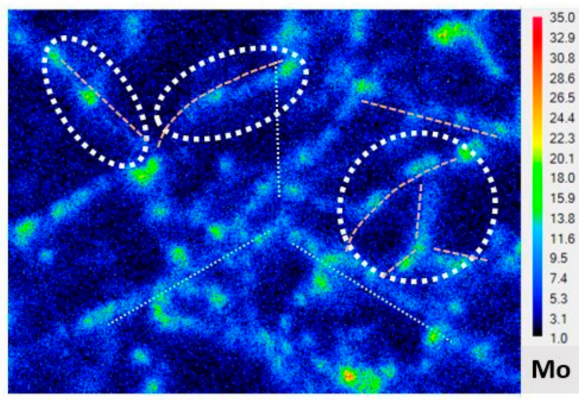

Figure 7. SEM, TEM, and EPMA analysis of as-welded ICHAZ after creep test at $600{ }^{\circ} \mathrm{C} / 200 \mathrm{MPa}$ : (a) SEM/BSE image; $(\mathbf{b}, \mathbf{c})$ TEM bright field image (including EDS analysis of the precipitates marked with arrows); and (d-f) EPMA elemental maps for $\mathrm{Cr}, \mathrm{W}$, and Mo, respectively.

It is well known that Laves phases are formed preferentially on the grain boundaries adjacent to Cr-rich $\mathrm{M}_{23} \mathrm{C}_{6}$ carbides, and then they gradually swallow the $\mathrm{M}_{23} \mathrm{C}_{6}$ carbides in close vicinity due to the rearrangement of the alloy elements (Cr, Mo, and W) $[11,12,22,39-42]$, which is in agreement with the results of this study (Figure $7 \mathrm{~b}$ ). However, a lot of the Wand Mo-rich Laves phases were also observed at the newly formed fine PAGBs without $\mathrm{M}_{23} \mathrm{C}_{6}$ carbides after the creep (Figure 7a,c). The EPMA analysis confirmed that the high concentration of $\mathrm{W}$ and Mo does not appear to correlate with the Cr-rich $\mathrm{M}_{23} \mathrm{C}_{6}$ carbide (marked with white dotted circles in Figure 7d-f).

In order to investigate the distinctive location for Laves phase formation in the ICHAZ, nano-indentation test was carried out on the as-welded joints before the creep test, and the results are shown in Figure 8. Because the penetration depth of the nanoindentation tip was extremely small $(\sim 200 \mathrm{~nm})$, the nano-indentation test was performed on the as-polished specimens (i.e., before etching), and then SEM observation was carried out after etching. Figure 8a shows SEM images of the as-welded ICHAZ after the nanoindentation test, and hardness values are presented in the figure. The high hardness values were mostly associated with the untempered martensite phase, which was re-austenitized 
during heating in the weld thermal cycle. On the other hand, the lower hardness values were attributed to the untransformed microstructure, which was merely tempered during the weld thermal cycle. A boxplot analysis was obtained using more than 100 indents (spacing between the indents: $7 \mu \mathrm{m}$ ) in each subzone, and a great variation in hardness was observed in the ICHAZ (Figure 8b). A comparison of Figures 7 and 8 a revealed that the Laves phase appeared corresponding well to the hard/soft grain boundaries in the ICHAZ. Nucleation and coarsening of the Laves phase are strongly promoted by external stress [39,43-45]. It seems that great difference in hardness between hard and soft grain leads to higher stress-strain concentration at the newly formed PAGBs during creep, which may have a significant effect on the Laves phase precipitation.

(a)
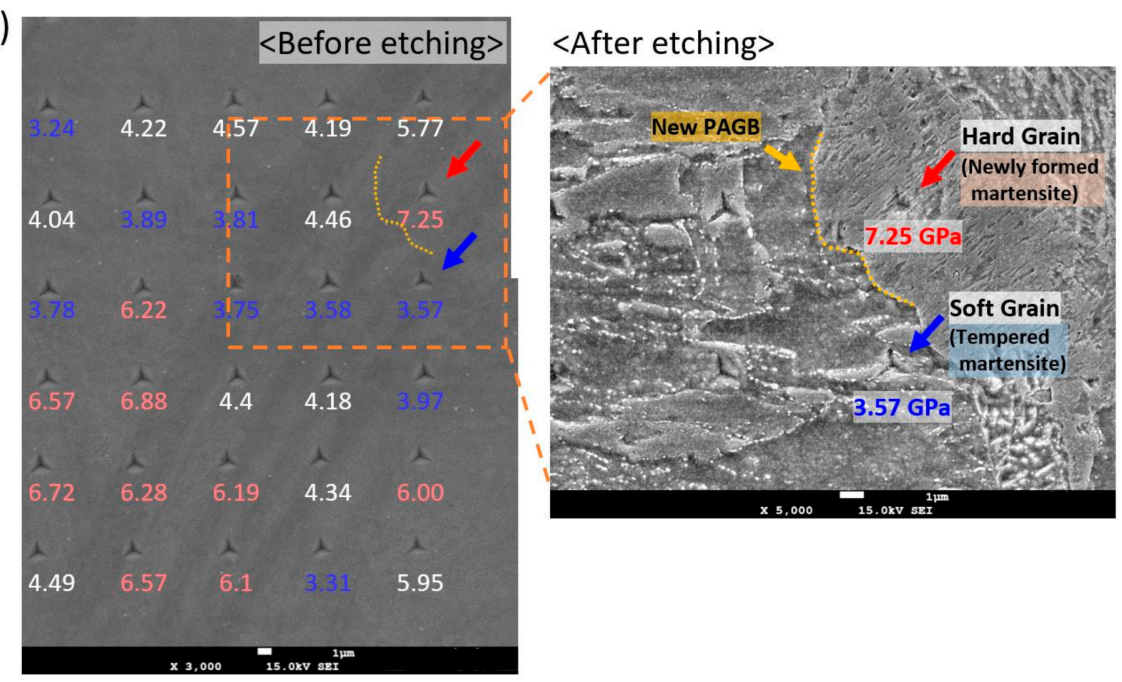

(b)
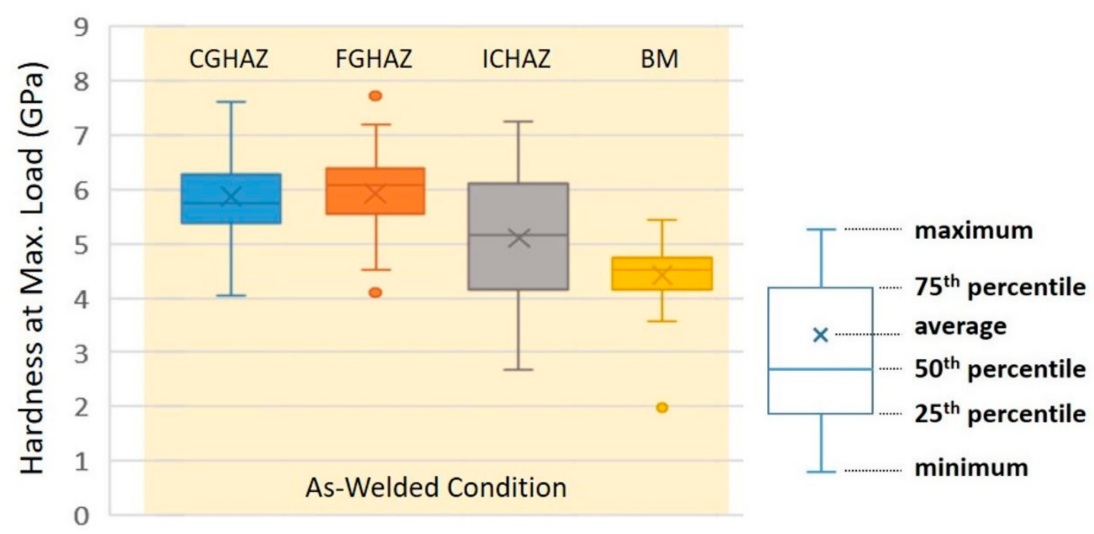

Figure 8. Results of nano-indentation test: (a) microstructure of the ICHAZ in the as-welded condition (hardness values are presented in the figure) and (b) boxplot analysis of each subzone hardness.

The results above clearly indicate that the microscale strength inhomogeneity of the ICHAZ microstructure attributed to the formation of the Laves phase at the PAGBs during creep exposure. The localized creep deformation during tertiary creep stage along with enhanced recovery facilitated the nucleation and growth of voids around the Laves phase particles (Figure 5c), which resulted in Type IV cracking in the ICHAZ. 


\subsection{Retardation of Type IV Cracking for $738^{\circ} \mathrm{C}$ PWHTed Condition}

The specimens with PWHT temperature of $738^{\circ} \mathrm{C}$ exhibited higher creep life than that of the as-welded and $688^{\circ} \mathrm{C}$ PWHT conditions even though the Type IV cracking fracture occurred in the ICHAZ (Figures 2 and 3). During the secondary creep stage, all the specimens fractured with Type IV cracking showed almost the same increase in the creep strain $(\Delta \varepsilon: 0.11-0.14 \%)$. However, in the $738{ }^{\circ} \mathrm{C}-8 \mathrm{~h}$ PWHTed condition, the onset of the tertiary creep stage was retarded to a later time than that of the other specimens. As shown in Figure 4, the hardness profiles before and after the creep tests of the $738^{\circ} \mathrm{C}-8 \mathrm{~h}$ PWHTed specimens show that the hardness of ICHAZ was maintained constantly during creep, which suggests that no significant local recovery occurred during the secondary creep stage. Therefore, a longer duration of the secondary creep stage results in a lower minimum creep rate and longer rupture life. The creep rupture life is inversely proportional to the minimum creep rate, and it is known as the Monkman-Grant relationship [9,36,42,46].

Figure 9 shows the precipitates formed in the ICHAZ after the creep test, and the corresponding BSE images are shown to distinguish the $\mathrm{W}$ - and Mo-rich Laves phase (bright contrast) from the $\mathrm{M}_{23} \mathrm{C}_{6}$ particles (dark contrast). With an increase in the PWHT temperature and holding time, the density of $\mathrm{Cr}$-rich carbides in the ICHAZ increased, but the mean size of those carbides was almost the same $(\sim 0.2 \mu \mathrm{m})$. The microstructural investigation of the creep specimens revealed significant precipitation and growth of the Laves phase during the creep test; however, the area fraction of the Laves phase precipitates decreased as the PWHT temperature and holding time increased (from $2.51 \%$ to $1.00 \%$ ). Especially, in the $738^{\circ} \mathrm{C}-8 \mathrm{~h}$ PWHTed condition, less amount of Laves phase were distributed with the $\mathrm{Cr}$-rich $\mathrm{M}_{23} \mathrm{C}_{6}$ carbides and were rarely observed in the newly formed fine PAGBs, in contrast with the other specimens (Figure 9c).

Figure 10 shows the nano-indentation hardness variation in the ICHAZ under various PWHT conditions. Hardness variation in the ICHAZ decreased with an increasing the PWHT temperature and holding time as a result of sufficient tempering of fresh martensite. It seems that the formation of Laves phase is suppressed in the ICHAZ due to the limited available nucleation site on the newly formed PAGBs by reducing the microscale strength mismatch between hard and soft grain (Figure 9c), which retards the onset of the tertiary creep stage.

In the tertiary creep stage, the creep rate increases rapidly with time after the secondary creep stage, resulting in failure. Normally, an increase of the creep rate is attributed to enhancement of the microstructural process, such as coarsening of precipitates and subgrains, and the nucleation and growth of creep voids $[9,10,33,36,46]$. As the creep exposure time increased, creep voids linked to each other and finally formed microcracks, which resulted in Type IV cracking fracture in the ICHAZ. Considerable increase in the duration of the tertiary creep stage was also observed for the $738^{\circ} \mathrm{C}-8 \mathrm{~h}$ PWHT condition (Figure 2), which means that the reduced formation of the Laves phase enhanced resistance to void growth or crack propagation after formation of the creep voids. 
(a) $688^{\circ} \mathrm{C}-8 \mathrm{~h}$ PWHT $\left(t_{r}: 2973 \mathrm{~h}\right)$

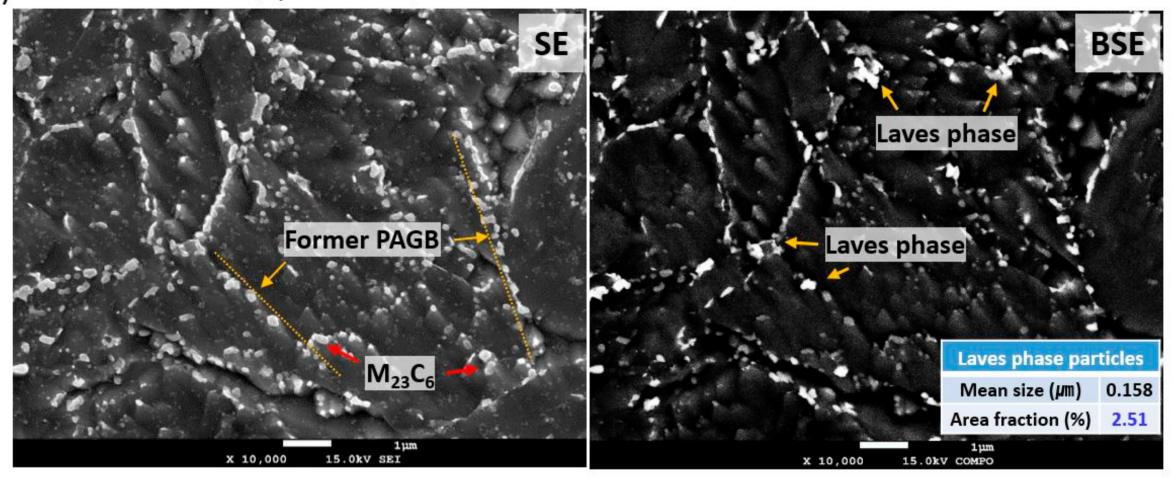

(b) $738^{\circ} \mathrm{C}-4 \mathrm{~h}$ PWHT $\left(t_{r}: 3242 \mathrm{~h}\right)$

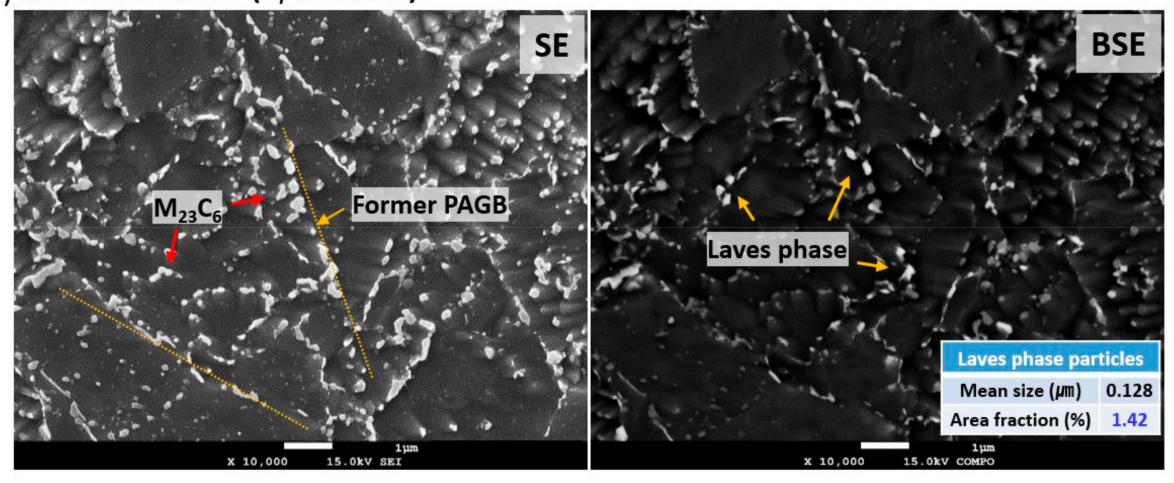

(c) $738^{\circ} \mathrm{C}-8 \mathrm{~h}$ PWHT $\left(t_{r}: 5043 \mathrm{~h}\right)$

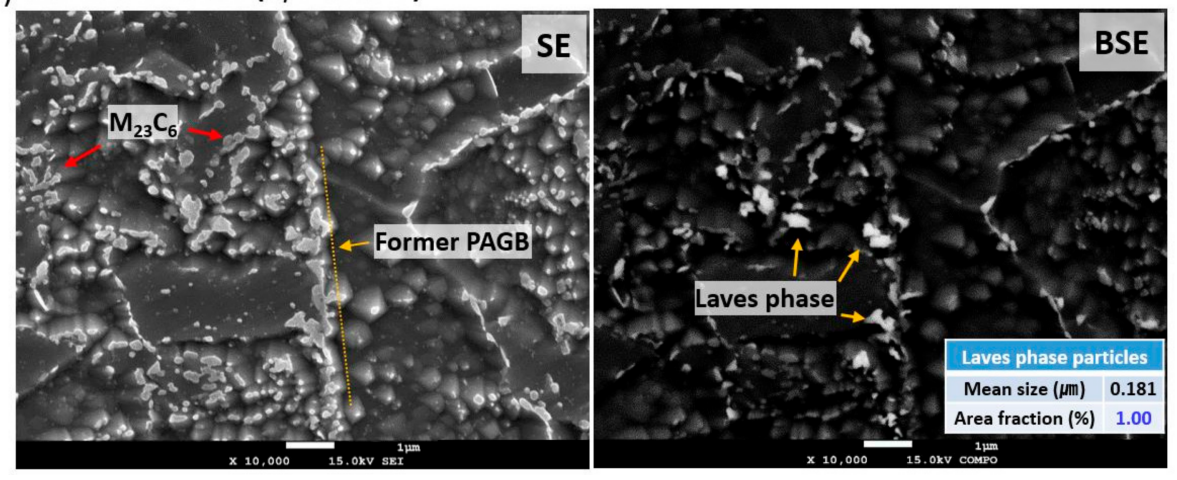

Figure 9. SEM and corresponding BSE images of the ICHAZ after creep test (including mean particle size and area percentage of the Laves phase particles): (a) $688^{\circ} \mathrm{C}-8 \mathrm{~h}$; (b) $738^{\circ} \mathrm{C}-4 \mathrm{~h}$; and (c) $738{ }^{\circ} \mathrm{C}-8 \mathrm{~h}$ PWHTed specimens.

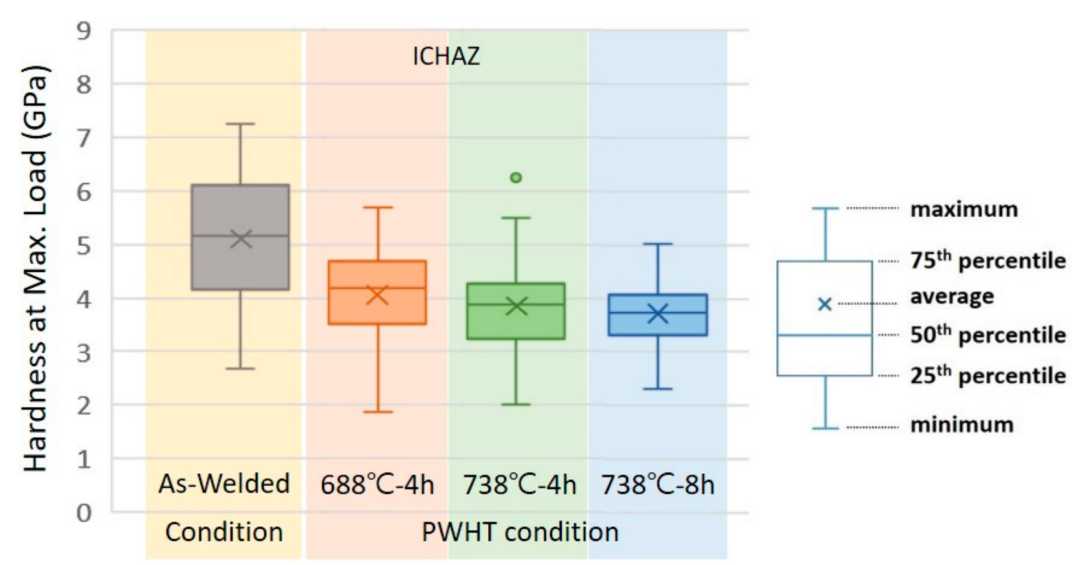

Figure 10. Hardness variation in the ICHAZ measured by nano-indentation. 
Typical SEM fractographs of creep tested specimens are shown in Figure 11. In the $688^{\circ} \mathrm{C}-8 \mathrm{~h}$ PWHTed specimen, SEM investigations on the fracture surface revealed large shallow creep cavities (Figure 11a). On the other hand, in the $738^{\circ} \mathrm{C}-8 \mathrm{~h}$ PWHTed specimen, the creep cavities were relatively deep, and numerous microvoids were present between large cavities (shown by arrows in Figure 11b). With creep damage accumulation in the ICHAZ, the distance between creep cavities keeps decreasing until the ligament is unable to withstand the load, and the remaining areas are subjected to tensile fracture with fine voids because of the increased stress. The deeper cavities mean that the growth or connection of cavities needs more creep deformation. It is suggested that the sparse distribution of Laves phase particles (Figure 9c) and the sufficient solid solution strengthening of the matrix contribute to increased Type IV cracking resistance during the tertiary creep stage. By application of PWHT at $738^{\circ} \mathrm{C}$ for $8 \mathrm{~h}$, a homogenized microstructure of the ICHAZ was obtained, and the combined effect of suppression of the Laves phase formation and sufficient solid solution strengthening results in retardation of Type IV cracking.

(a) $688^{\circ} \mathrm{C}-8 \mathrm{~h}$ PWHTed

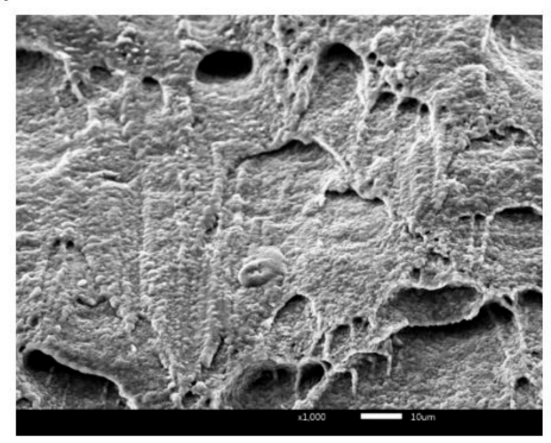

(b) $738^{\circ} \mathrm{C}-8$ h PWHTed

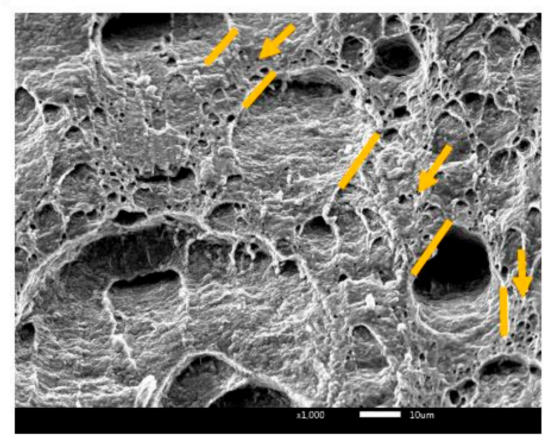

Figure 11. Typical fracture morphologies of creep specimens with different PWHT conditions: (a) $688^{\circ} \mathrm{C}-8 \mathrm{~h}$ and (b) $738^{\circ} \mathrm{C}-8 \mathrm{~h}$ PWHTed specimens.

\section{Conclusions}

In this study, the effect of PWHTs on Type IV creep failure of $10 \% \mathrm{Cr}$ martensitic steel welds was investigated. The creep tests were carried out at $600{ }^{\circ} \mathrm{C}$ under a stress of $200 \mathrm{MPa}$, and it was found that the proper selection of PWHT temperature and holding time can suppress formation of Laves phase during creep test and results in retardation of Type IV failure. The main conclusions are as follows:

1. As-welded (No-PWHT), $688^{\circ} \mathrm{C}$ and $738^{\circ} \mathrm{C}$ PWHTed specimens showed Type IV cracking failure because of localized creep deformation and growth of voids around Laves phase particles in the ICHAZ. The creep properties of the PWHTed joints at $688^{\circ} \mathrm{C}$ were similar to those of the as-welded joint without PWHT.

2. By the application of PWHT at $738^{\circ} \mathrm{C}$ for $8 \mathrm{~h}$, a homogenized microstructure of the ICHAZ was obtained, and the combined effect of suppression of Laves phase formation and sufficient solid solution strengthening resulted in the extension of creep life even though Type IV failure occurred.

3. The specimens with PWHT at $788{ }^{\circ} \mathrm{C}$ exhibited the shortest creep life, and a shift in creep rupture location was observed from the ICHAZ to the $10 \% \mathrm{Cr}$ steel BM. The creep rupture in the BM was mainly caused by plastic deformation due to the softened matrix by excessive tempering at high PWHT temperature. 
Author Contributions: Conceptualization, N.K. (Namkyu Kim), C.-Y.K., and N.K. (Namhyun Kang); methodology, N.K. (Namkyu Kim); software, Y.K.; validation, S.S., C.-Y.K., and N.K. (Namhyun Kang); formal analysis, J.B.; investigation, N.K. (Namkyu Kim), Y.K., and S.-M.S.; resources, N.K. (Namkyu Kim); data curation, N.K. (Namkyu Kim), J.B., and S.-M.S.; writing-original draft preparation, N.K. (Namhyun Kang), Y.K., and S.-M.S.; writing-review and editing, S.S, C.-Y.K., and N.K. (Namhyun Kang); visualization, J.B.; supervision, C.-Y.K. and N.K. (Namhyun Kang). All authors have read and agreed to the published version of the manuscript.

Funding: This research received no external funding.

Institutional Review Board Statement: Not applicable.

Informed Consent Statement: Not applicable.

Data Availability Statement: Not applicable.

Acknowledgments: This work was supported by the National Research Foundation of Korea (NRF) grant funded by the Korea government (MSIT) [NRF-2019M2D2A205091812], and by the Korea Institute of Energy Technology Evaluation and Planning (KETEP) and the Ministry of Trade, Industry and Energy (MOTIE) of the Republic of Korea [20206500000010].

Conflicts of Interest: The authors declare no conflict of interest.

\section{References}

1. Abe, F.; Tabuchi, M. Microstructure and creep strength of welds in advanced ferritic power plant steels. Sci. Technol. Weld. Join. 2004, 9, 22-30. [CrossRef]

2. Abe, F. Precipitate design for creep strengthening of $9 \% \mathrm{Cr}$ tempered martensitic steel for ultra-supercritical power plants. Sci. Technol. Adv. Mater. 2008, 9, 013002. [CrossRef] [PubMed]

3. Viswanathan, R.; Coleman, K.; Rao, U. Materials for ultra-supercritical coal-fired power plant boilers. Int. J. Press. Vessel. Pip. 2006, 83, 778-783. [CrossRef]

4. Sroka, M.; Zieliński, A.; Mikuła, J. The service life of the repair welded joint of Cr-Mo / Cr-Mo-V. Arch. Metall. Mater. 2016, 61, 969-974. [CrossRef]

5. Golański, G.; Zieliński, A.; Zielińska-Lipiec, A. Degradation of microstructure and mechanical properties in martensitic cast steel after ageing. Mater. Werkst. 2015, 46, 248-255. [CrossRef]

6. Zieliński, A.; Dobrzański, J.; Purzyńska, H.; Sikora, R.; Dziuba-Kałuża, M.; Kania, Z. Evaluation of creep strength of heterogeneous welded joint in HR6W alloy and Sanicro 25 steel. Arch. Metall. Mater. 2017, 62, 2057-2064. [CrossRef]

7. Joseph, C.; Persson, C.; Colliander, M.H. Influence of heat treatment on the microstructure and tensile properties of Ni-base superalloy Haynes 282. Mater. Sci. Eng. A 2017, 679, 520-530. [CrossRef]

8. Shin, K.; Kim, J.; Terner, M.; Kong, B.; Hong, H. Effects of heat treatment on the microstructure evolution and the high-temperature tensile properties of Haynes 282 superalloy. Mater. Sci. Eng. A 2019, 751, 311-322. [CrossRef]

9. Abe, F. Creep Behavior, Deformation Mechanisms, and Creep Life of Mod.9Cr-1Mo Steel. Metall. Meter. Trans. A 2015, $46 A, 5610-5625$. [CrossRef]

10. Sakthivel, T.; Laha, K.; Vasudevan, M.; Koteswara Rao, M.; Panneer Selvi, S. Type IV cracking behaviour of modified 9Cr-1Mo steel weld joints. Mater. High Temp. 2016, 33, 137-153. [CrossRef]

11. Zhang, Q.; Zhang, J.; Zhao, P.; Huang, Y.; Yang, Y.; Zhao, Y. Microstructure of $10 \%$ Cr martensitic heat-resistant steel welded joints and type IV cracking behavior during creep rupture at $650^{\circ} \mathrm{C}$. Mater. Sci. Eng. A 2015, 638, 30-37. [CrossRef]

12. Xu, Y.; Nie, Y.; Wang, M.; Li, W.; Jin, X. The effect of microstructure evolution on the mechanical properties of martensite ferritic steel during long-term aging. Acta Mater. 2017, 131, 110-122. [CrossRef]

13. Laha, K.; Chandravathi, K.S.; Rao, K.B.S.; Mannan, S.L.; Sastry, D.H. An Assessment of Creep Deformation and Fracture Behavior of 2.25Cr-1Mo Similar and Dissimilar Weld Joints. Metall. Meter. Trans. A 2001, 32A, 115-124. [CrossRef]

14. Zhang, Y.; Li, K.; Cai, Z.; Pan, J. Creep rupture properties of dissimilar metal weld between Inconel 617B and modified 9\%Cr martensitic steel. Mater. Sci. Eng. A 2019, 764, 138185. [CrossRef]

15. Cao, J.; Gong, Y.; Yang, Z. Microstructural analysis on creep properties of dissimilar materials joints between T92 martensitic and HR3C austenitic steels. Mater. Sci. Eng. A 2011, 528, 6103-6111. [CrossRef]

16. Zhao, L.; Jing, H.; Xu, L.; Han, Y.; Xiu, J. Experimental study on creep damage evolution process of Type IV cracking in 9Cr-0.5Mo-1.8W-VNb steel welded joint. Eng. Fail. Anal. 2012, 19, 22-31. [CrossRef]

17. Jun, S.; Im, S.; Moon, J.; Lee, C.; Hong, H. Technical Issues in Fusion Welding of Reduced Activation Ferritic/Martensitic Steels for Nuclear Fusion Reactors. J. Weld. Join. 2020, 38, 47-55. [CrossRef]

18. Lee, J.S.; Maruyama, K. Mechanism of Microstructural Deterioration Preceding Type IV Failure in Weldment of Mod.9Cr-1Mo Steel. Met. Mater. Int. 2015, 21, 639-645. [CrossRef] 
19. Sakthivel, T.; Vasudevan, M.; Laha, K.; Parameswaran, P.; Chandravathi, K.S.; Panneer Selvi, S.; Maduraimuthu, V.; Mathew, M.D. Creep rupture behavior of $9 \mathrm{Cr}-1.8 \mathrm{~W}-0.5 \mathrm{Mo}-\mathrm{VNb}$ (ASME grade 92) ferritic steel weld joint. Mater. Sci. Eng. A 2014, 591, 111-120. [CrossRef]

20. Li, L.; Silwal, B.; Deceuster, A. Creep rates of heat-affected zone of grade 91 pipe welds as determined by stress-relaxation test. Int. J. Press. Vessel. Pip. 2016, 146, 95-103. [CrossRef]

21. Pandey, C.; Mahapatra, M.M.; Kumar, P. Effect of post weld heat treatments on fracture frontier and type IV cracking nature of the crept P91 welded sample. Mater. Sci. Eng. A 2018, 731, 249-265. [CrossRef]

22. Pandey, C.; Mahapatra, M.M.; Kumar, P.; Kumar, S.; Sirohi, S. Effect of post weld heat treatments on microstructure evolution and type IV cracking behavior of the P91 steel welds joint. J. Mater. Process. Tech. 2019, 266, 140-154. [CrossRef]

23. Wang, Y.; Li, L.; Kannan, R. Transition from Type IV to Type I cracking in heat-treated grade 91 steel weldments. Mater. Sci. Eng. A 2018, 714, 1-13. [CrossRef]

24. Parker, J.D.; Siefert, J.A. Weld repair of Grade 91 piping and components in power generation applications, creep performance of repair welds. Mater. High Temp. 2015. [CrossRef]

25. Taniguchi, G.; Yamashita, K. Effects of Post Weld Heat Treatment (PWHT) Temperature on Mechanical Properties of Weld Metals for High-Cr Ferritic Heat-Resistant Steel. Kobleco Technol. Rev. 2013, 32, 33-39.

26. Abson, D.J.; Rothwell, J.S. Review of type IV cracking of weldments in $9-12 \%$ Cr creep strength enhanced ferritic steels. Int. Mater. Rev. 2013, 58, 437-473. [CrossRef]

27. Kim, M.; Kang, Y.; Kim, N.; Lee, S.; Song, S.; Kang, N. PWHT Cracking Susceptibility in the HAZ of Martensitic $10 \mathrm{Cr}$ Steel for A-USC Power Plant. Korean J. Met. Mater. 2019, 57, 430-437. [CrossRef]

28. Bang, J.; Kang, Y.; Kim, N.; Seo, S.; Lee, S.; Song, S.; Kang, N. Effect of Aging Heat Treatment Conditions on the Mechanical Properties and Microstructure of Base and Weld Metal of Alloy 282 Superalloy. Korean J. Met. Mater. 2020, 58, 540-549. [CrossRef]

29. Dimmler, G.; Weinert, P.; Kozeschnik, E.; Cerjak, H. Quantification of the Laves phase in advanced 9-12\% Cr steels using a standard SEM. Mater. Charact. 2003, 51, 341-352. [CrossRef]

30. Lee, J.S.; Armaki, H.G.; Maruyama, K.; Muraki, T.; Asahi, H. Causes of breakdown of creep strength in $9 \mathrm{Cr}-1.8 \mathrm{~W}-0.5 \mathrm{Mo}-\mathrm{VNb}$ steel. Mater. Sci. Eng. A 2006, 428, 270-275. [CrossRef]

31. Kim, M.; Kwak, S.; Choi, I.; Lee, Y.; Suh, J.; Fleury, E.; Jung, W.; Son, T. High-temperature tensile and creep deformation of cross-weld specimens of weld joint between T92 martensitic and Super304H austenitic steels. Mater. Charact. 2014, 97, 161-168. [CrossRef]

32. Laha, K.; Chandravathi, K.S.; Parameswatan, P.; Rao, K.B.S.; Mannan, S.L. Characterization of Microstructures across the Heat-Affected Zone of the Modified 9Cr-1Mo Weld Joint to Understand Its Role in Promoting Type IV Cracking. Metall. Meter. Trans. A 2007, 38A, 58-68. [CrossRef]

33. Skleničk, V.; Kuchařová, K.; Svobodová, M.; Kvapilová, M.; Král, P.; Horváth, L. Creep properties in similar weld joint of a thick-walled P92 steel pipe. Mater. Charact. 2016, 119, 1-12. [CrossRef]

34. Xu, L.; Wang, Y.; Jing, H.; Zhao, L.; Han, Y. Deformation Mechanism and Microstructure Evolution of T92/S30432 Dissimilar Welded Joint During Creep. J. Mater. Eng. Perform. 2016, 25, 3960-3971. [CrossRef]

35. Maddi, L.; Deshmukh, G.S.; Ballal, A.R.; Peshwe, D.R.; Paretkar, R.K.; Laha, K.; Mathew, M.D. Effect of Laves phase on the creep rupture properties of P92 steel. Mater. Sci. Eng. A 2016, 668, 215-223. [CrossRef]

36. Zhang, Y.; Jing, H.; Xu, L.; Zhao, L.; Han, Y.; Zhao, Y. High-temperature deformation and fracture mechanisms of an advanced heat resistant Fe-Cr-Ni alloy. Mater. Sci. Eng. A 2017, 686, 102-112. [CrossRef]

37. Wang, Y.; Kannan, R.; Li, L. Insight into Type IV cracking in Grade 91 steel weldments. Mater. Des. 2020, 190, 108570. [CrossRef]

38. Pandey, C.; Mahapatra, M.M.; Kumar, P.; Thakre, J.G.; Saini, N. Role of evolving microstructure on the mechanical behaviour of P92 steel welded joint in as-welded and post weld heat treated state. J. Mater. Process. Tech. 2019, 263, 241-255. [CrossRef]

39. Isik, M.I.; Kostka, A.; Yardley, V.A.; Pradeep, K.G.; Duarte, M.J.; Choi, P.P.; Raabe, D.; Eggelera, G. The nucleation of Mo-rich Laves phase particles adjacent to $\mathrm{M}_{23} \mathrm{C}_{6}$ micrograin boundary carbides in $12 \% \mathrm{Cr}$ tempered martensite ferritic steels. Acta Mater. 2015, 90, 94-104. [CrossRef]

40. Xu, Y.; Wang, M.; Wang, Y.; Gu, T.; Chen, L.; Zhou, X.; Ma, Q.; Liu, Y.; Huang, J. Study on the nucleation and growth of Laves phase in a 10\% Cr martensite ferritic steel after long-term aging. J. Alloys Compd. 2015, 621, 93-98. [CrossRef]

41. Isik, M.I.; Kostka, A.; Eggeler, G. On the nucleation of Laves phase particles during high-temperature exposure and creep of tempered martensite ferritic steels. Acta Mater. 2014, 81, 230-240. [CrossRef]

42. Ennis, P.J.; Zielinska-Lipiec, A.; Wachter, O.; Czyrska-Filemonowicz, A. Microstructural stability and creep rupture strength of the martensitic steel P92 for advanced power plant. Acta Mater. 1997, 45, 4901-4907. [CrossRef]

43. Sauthoff, G. Influence of Stresses on Precipitation. J. Phys. IV Proc. EDP Sci. 1996, 6, C1-87-C1-97. [CrossRef]

44. Cui, J.; Kim, I.; Kang, C.; Miyahara, K. Creep Stress Effect on the Precipitation Behavior of Laves Phase in Fe- $10 \% \mathrm{Cr}-6 \% \mathrm{~W}$ Alloys. ISIJ Int. 2001, 41, 368-371. [CrossRef]

45. Wang, X.; Wang, X.; Li, H.; Wu, H.; Ren, Y.; Liu, H.W.; Liu, H. Laves phase precipitation behavior in the simulated fine-grained heat-affected zone of creep strength enhanced ferritic steel P92 and its role in creep void nucleation and growth. Weld World 2017, 61, 231-239. [CrossRef]

46. Choudhary, B.K. Tertiary creep behaviour of 9Cr-1Mo ferritic steel. Mater. Sci. Eng. A 2013, 585, 1-9. [CrossRef] 